\title{
Echocardiographic optimization favors greater reduction in left ventricular end-diastolic volume compared to electrocardiographic optimization in patients with cardiac resynchronization therapy
}

\section{(D)Marija Brestovac*, DBlanka Glavaš Konja, (D)Martina Lovrić Benčić, \\ (D) Vlatka Rešković Lukšić, \\ (D) Kristina Gašparović, (D)Jadranka Šeparović Hanževački}

University of Zagreb School of Medicine, University Hospital Centre Zagreb, Zagreb, Croatia
RECEIVED:

March 28, 2021

ACCEPTED:

April 2, 2021
KEYWORDS: cardiac resynchronization therapy, echocardiographic optimization, left ventricular volume. CITATION: Cardiol Croat. 2021;16(5-6):203. | https://doi.org/10.15836/ccar2021.203

*ADDRESS FOR CORRESPONDENCE: Marija Brestovac, Klinički bolnički centar Zagreb, Kišpatićeva 12, HR-10000 Zagreb, Croatia. / Phone: +385-99-7742-627 / E-mail: marija.brestovac@gmail.com

ORCID:Marija Brestovac, https://orcid.org/0000-0003-1542-2890 • Blanka Glavaš Konja, https://orcid.org/0000-0003-1134-4856 Martina Lovrić Benčić, https://orcid.org/0000-0001-8446-6120 • Vlatka Rešković Lukšić, https://orcid.org/0000-0002-4721-3236 Kristina Gašparović, https://orcid.org/0000-0002-1191-4831 • Jadranka Šeparović Hanževački, https://orcid.org/0000-0002-3437-6407

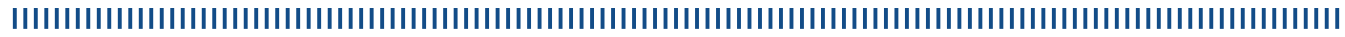

Introduction: Cardiac resynchronization therapy (CRT) is a widely used method in the treatment of symptomatic patients with advanced heart failure and LBBB. Its beneficial impact on the reduction of left ventricular (LV) volumes has already been shown., ${ }^{1,2}$ The aim of this study was to determine if echocardiographic optimization of CRT pacing intervals (ECHO) after CRT device implantation has a favorable impact on LV volume change compared to electrocardiographic optimization (ECG).

Patients and Methods: An overall of 147 patients with implanted CRT according to guidelines were included in this study and divided into two groups according to the CRT optimization method (N=70 in ECG arm an N=77 in ECHO arm). ECG optimization was performed using 12-lead electrocardiogram, fusion-optimized intervals, intracardiac electrogram-based algorithms and electrocardiographic imaging. ECHO optimization implied correction of atrioventricular, inter- and intraventricular dyssynchrony using echocardiographic imaging. The change in LV end-diastolic (EDV), end-systolic (ESV) and stroke volume (SV) as well as LV ejection fraction (EF) was compared between groups, before and 6 months after CRT implantation.

Results: EDV and ESV significantly decreased and EF increased in both groups. In the ECHO a statistically significant reduction in EDV compared to ECG was present $(p=0.028)$. According to greater EDV reduction, SV significantly decreased in ECHO ( $p=0.026)$. No significance was observed in ESV change between groups ( $\mathrm{p}=0.063)$ (Table $\mathbf{1})$.

Conclusion: ECHO optimization of CRT leads to a more significant reduction of EDV compared to ECG optimization after 6 months of follow up.

TABLE 1. Left ventricle volumes and ejection fraction change before and 6 months after cardiac resynchronization therapy between the analyzed groups.

\begin{tabular}{cccccccc}
\hline \multicolumn{3}{c}{ ECG $(\mathrm{N}=70)$} & \multicolumn{3}{c}{ ECHO $(\mathrm{N}=77)$} \\
\hline & Before CRT & $\begin{array}{c}\text { 6 months } \\
\text { after CRT }\end{array}$ & $\begin{array}{c}\text { Mean change, } \\
\text { SD }\end{array}$ & Before CRT & $\begin{array}{l}6 \text { months } \\
\text { after CRT }\end{array}$ & $\Delta$ & \\
\hline EDV $(\mathrm{ml})$ & 218.81 & 167.48 & $51.32( \pm 64.25)$ & 231.81 & 157.53 & $74.28( \pm 80.25)$ & $\mathrm{p}=\mathbf{0 . 0 2 8}$ \\
\hline ESV $(\mathrm{ml})$ & 162.27 & 112.25 & $50.01( \pm 59.38)$ & 169.67 & 102.57 & $67.1( \pm 75.02)$ & $\mathrm{p}=0.063$ \\
\hline SV $(\mathrm{ml})$ & 56.54 & 55.23 & $1.31( \pm 16.46)$ & 62.14 & 54.96 & $7.18( \pm 19.66)$ & $\mathrm{p}=\mathbf{0 . 0 2 6}$ \\
\hline EF $(\%)$ & 26.67 & 36.79 & $10.11( \pm 8.39)$ & 26.97 & 39.13 & $12.16( \pm 10.80)$ & $\mathrm{p}=0.1$ \\
\hline
\end{tabular}

EDV - left ventricular end-diastolic volume, ESV - left ventricular end-systolic volume, SV - left ventricular stroke volume, EF - left ventricular ejection fraction, SD - standard deviation.

LITERATURE IIIIIIIIIIIIIIIIIIIIIIIIIIIIIIIIIIIIIIIIIIIIIIIIIIIIIIIIIIIIIIIIIIIIIIIIIIIIIIIIIIIIIIIIIIIIIIIII

1. St John Sutton MG, Plappert T, Abraham WT, Smith AL, DeLurgio DB, Leon AR, et al; Multicenter InSync Randomized Clinical Evaluation (MIRACLE) Study Group. Effect of cardiac resynchronization therapy on left ventricular size and function in chronic heart failure. Circulation. $2003 \mathrm{Apr}$ 22:107(15):1985-90. https://doi.org/10.1161/01.CIR.0000065226.24159.E9

2. St John Sutton M, Cerkvenik J, Borlaug BA, Daubert C, Gold MR, Ghio S, et al. Effects of Cardiac Resynchronization Therapy on Cardiac Remodeling and Contractile Function: Results From Resynchronization Reverses Remodeling in Systolic Left Ventricular Dysfunction (REVERSE). J Am Heart Assoc. 2015 Sep 11;4(9):e002054. https://doi.org/10.1161/JAHA.115.002054 